\title{
Using of mucilage palm oil in the toilet soap production
}

\author{
By Adel Y. Girgis \\ Agricultural Research Centre, Food Technology Res. Institute, Oils and Fats Res. Dept. 9 \\ El-Gamaa St., Giza, Egypt.
}

\section{RESUMEN}

Uso de mucilagos de aceite de palma en la producción de jabón de tocador.

Mucilagos de aceite de palma (M.P.O.) fueron obtenidos mediante la etapa de refinación física del aceite de palma crudo. Los componentes de M.P.O. tuvieron un alto contenido en ácidos grasos libres (82.2\%) con cantidades pequeñas de aceites neutros (11.9\%), mientras que el contenido residual (materia insaponificable e impurezas) fue del $2.1 \%$ además del $3.8 \%$ de agua. Los resultados indicaron que los colores de M.P.O., sebo y aceite de almendra de palma mejoraron después de la decoloración. Ocho muestras de jabón $\left(n .^{o s} 1-8\right)$ fueron preparadas a partir de mezclas grasas decoloradas de mucilagos de aceite de palma, sebo y aceite de almendra de palma en diferentes proporciones. Los resultados mostraron que los contenidos de humedad de muestras de jabones $n .{ }^{\circ} 2,7$ y 8 fueron altos comparados con el jabón control (muestra $n .{ }^{\circ} 1$ ), y por tanto su materia grasa total fueron menores que la encontrada en el jabón control (muestra $n^{\circ}{ }^{0} 1$ ). Los resultados señalaron que la materia insaponificable de los jabones $n^{\text {.s }} 2,7$ y 8 fueron mayores que las obtenidas de los otros jabones. No se observaron grandes diferencias en el alcali libre de todos los jabones preparados (rango de 0.06 a $0.09 \%$ ). Por otra parte, se encontraron grandes variaciones en el aceite libre de todas las muestras de jabones ( $\left.{ }^{0 .}{ }^{02} 2-8\right)$ comparadas con el del jabón control (muestra $n .{ }^{\circ} 1$ ), excepto las muestras de jabones $n .^{\text {os }} 2,7$ y 8 , las cuales registraron valores muy altos. Las mejores muestras de jabón en cuanto al color siguieron el siguiente orden creciente: $n^{\text {os }} 1>3>4>5>6>7>8>2$. Los resultados mostraron que las mejores muestras de jabón en cuanto a las propiedades físicas siguieron el siguiente orden creciente: jabón $n .^{\circ} 3>$ jabón n. $.^{\circ} 4>$ jabón n. ${ }^{\circ} 5>$ jabón $n .^{\circ} 6$ cuando fueron comparadas con el jabón control, ellos mostraron estructura firme y buena espuma, mientras que las otras muestras de jabón $\left(n^{0 .}{ }^{02}, 7\right.$ y 8 ) fueron de pobre calidad (esto es, bajas propiedades espumantes con colores intensos). Por consiguiente se puede concluir que los mucilagos de aceite de palma pueden ser usados como nuevo material graso para la fabricación de jabones de tocador en la proporción de un $40 \%$ de mezcla grasa.

PALABRAS-CLAVE: Aceite de palma - Jabón de tocador - Mucilago.

\section{SUMMARY}

Using of mucilage palm oil in the toilet soap production.

Mucilage palm oil (M.P.O.) was obtained from physical refining step for crude palm oil. The components of M.P.O. were high content of free fatty acids $(82.2 \%)$ with simple amount of neutral oil (11.9\%), while the residual content (unsaponifiable matter and impurities) was $2.1 \%$ and in addition to $3.8 \%$ water. The results indicated that the colours of M.P.O., tallow and palm kemel oil improved after bleaching. Eight soap samples $\left(n .^{\circ} 1-8\right)$ were prepared from bleached fatty blends of mucilage palm oil, tallow and palm kernel oil at different ratios. The results showed that the moisture contents of soap samples n. ${ }^{\circ s} 2,7$ and 8 were high compared with the standard soap (sample n. ${ }^{\circ}$ ), subsequently their total fatty matters became lower than that found in the control soap (sample n. ${ }^{\circ} 1$ ). The findings marked that the unsaponifiable matter of soaps n. ${ }^{\circ s} 2,7$ and 8 were higher compared with the other soaps. No high differences were observed in the free alkali of all soaps (range from 0.06 to $0.09 \%$ ). On the other hand, high differences were found in the free oil of all soap samples (n. ${ }^{\circ}$ 2-8) compared with the standard soap (sample n. ${ }^{\circ} 1$ ), except soap samples $n .{ }^{\circ s} 2,7$ and 8 , which record very high. The best soap samples in the colour were in the following increasing order: $n^{\text {os }} 1>$ $3>4>5>6>7>8>2$, respectively. The results showed that the better soap samples in the physical properties were in the following increasing order: soap n. ${ }^{\circ} 3>$ soap n. ${ }^{\circ} 4>$ soap n. ${ }^{\circ} 5>$ soap n. ${ }^{\circ} 6$ compared with the standard soap (sample n. ${ }^{\circ} 1$ ), where from firm structure with high foam, while the other soap samples (n. ${ }^{\text {os }} 2,7$ and 8) were poor quality (i.e., low lathering properties with deep colours).

Therefore, it could be concluded that mucilage palm oil can be used as a new fatty material for toilet soap manufacturing at ratio of $40 \%$ from the fatty blend.

KEY-WORDS: Mucilage - Palm oil - Toilet soap.

\section{INTRODUCTION}

Soap is one of the most effective cleaning agents in soft water (Joseph and Desal, 1991), while (Ainie et al., 1996) suggested that the soap is a mixture of the sodium salts of the following fatty acids: stearic, palmitic, myristic, lauric and oleic acids, which these acids are contribute to lathering and washing properties of the soaps. Karl (1991) assigned that a blend of $80 \%$ tallow fatty acids and $20 \%$ coconut fatty acids is used by most manufacturers. Kifli and Krishnan (1998), Ainie and Hamirin (1994) and Edmund (1994) tallied that palm oil and palm kernel oil can be used as alternatives to tallow and coconut oil, respectively. On the other hand, in Egypt, the manufacturing of toilet soap is making from a blend of $85 \%$ tallow or palm stearin or blend of them with $15 \%$ palm kernel oil (Ministry of Industry, 1997). Tandy and McPherson (1984) and Jan (1995) found that the residual foots from physical refining step for crude palm oil contain a great amount of free fatty acids (F.F.A.), neutral oil, unsaponifiable matter and pungent compounds. Woollatt (1985) stated that the mucilage is a by-product resulting from the physical refining of oils and is consumed in soap merely 
because it is unsuitable for most other purposes. Hamilton (1995) reported that the color of crude palm oil is one of the main problems during the processing operations. Tan et al., (1985) stated that carotenoids are responsible for the dark orange-red color of crude palm oil. Hydrogen peroxide solution is used to improve the color of palm oil using in the manufacture of soap (Woollatt, 1985). Respecting, the price of mucilage palm oil in Egypt (92.0\% total fatty acids) is about 1000 Egyptian pounds per ton (Arma Company for Food Industries, Egypt), while is about 2000 Egyptian pounds per ton for tallow (Ministry of Industry, 1997). The imported amounts of crude palm oil and its derivatives to Egypt were about 300000 tonnes during 1996-1997 (Ministry of Trade and Supply, 1997), which contain $1.0 \%$ free fatty acids. Hence, the expected contents from the fatty acids of palm oil (which it produces from the refining step) are about 3000 tonnes, while the production of toilet soap (78\% total fatty acids) in the Governomant Egyptian companies was 43000 tonnes during 1996-1997 (Ministry of Industry, 1997). Therefore, in Egypt, if mucilage palm oil will be used in the manufacturing of toilet soap, it will reduce the imported fatty material (tallow and palm stearin) at ratio of $10.5 \%$ and it will reduce the cost of toilet soap production at about 3.0 million Egyptian pounds per year.

Therefore, the purpose of this work was how mucilage palm oil (which is derived from physical refining step for crude palm oil) can be used as a new fatty material in toilet soap components to reduce the production cost and at the same time to maintenance on the environment from these wastes.

\section{MATERIALS AND METHODS}

\section{Materials}

- Tallow (T.), palm kernel oil (P.K.O.) and bleaching earth were brought from Cairo Oils and Soap Company, Cairo, Egypt.

- Sodium hydroxide and hydrogen peroxide solution were supplied from El-Gomhoria Company for Pharmaceutical, Cairo, Egypt.

- Sodium chloride was purchased from El-Nasr Salines Company, Alexandria Govemorate, Egypt.

- Mucilage palm oil (M.P.O.) was obtained from Arma Company for Food Industries, $10^{\text {th }}$ of Ramadan City, Egypt.

\section{Methods}

\section{Chemical and physical properties of the fatty materials}

Moisture and volatile matter (\%), acidity (\%) (as palmitic, oleic and lauric acids for mucilage palm oil, tallow and palm kernel oil, respectively), saponification value (S.V.), iodine number as Wii's (I.N.), unsaponifiable matter (\%), neutral oil (\%) and titer number ${ }^{\circ} \mathrm{C}$ (T.N.) were determined according to the methods described in the A.O.C.S. (1993), as well as, I.N.S. factor was calculated (as a difference between saponification value and iodine number) according to Ahmed (1981) and Small Business Publications (S.B.P.) (1987), while the color was measured by F.A.C. method found in the A.O.C.S (1993).

\section{Preparation of the fatty materials to methylation}

Fatty materials methyl esters [mucilage palm oil (M.P.O.), tallow (T.)and palm kernel oil (P.K.O.)] were prepared [using benzene: methanol: concentrated sulfuric acid $(10: 86: 4)$ and methylation was carried out for one hour at $\left.80-90^{\circ} \mathrm{C}\right]$ according to Stahl (1967).

\section{Isolation of the fatty acids}

Gas-liquid chromatography apparatus (Pye-Unican model 4550 ) was used for the fractionation of fatty acid methyl esters. The using conditions were identical to that described by Zygadlo et al., (1994). Peaks area were determined using spectrophysic integrator.

\section{Bleaching of the fatty materials}

- Tallow (T.) and palm kernel oil (P.K.O.) were bleached [using 4 and $2 \%$ bleaching earth, respectively] according to the method described by Chamkasem and Johnson (1988).

- Mucilage palm oil (M.P.O.) was bleached as follows: (1) M.P.O. was heated to $50-55^{\circ} \mathrm{C}$, and $2 \% \mathrm{H}_{2} \mathrm{O}_{2}$ solution was added gradually. (2) The sample was stirred at speed 80 round per min using stirrer for 20 min while maintaining a temperature of $50-55^{\circ} \mathrm{C}$. (3) The M.P.O. was then filtered through Whatman $\mathrm{N} .{ }^{\circ} 1$ filter paper at $55^{\circ} \mathrm{C}$ and the color was measured by F.A.C.

\section{Manufacturing of the soap samples}

One $\mathrm{kg}$ various blends (eight blends) of mucilage palm oil, tallow and palm kernel oil (Table I) were melted on a hot plate $\left(90^{\circ} \mathrm{C}\right.$ ), then the amount (see Table I) of total sodium hydroxide $(8.0 \mathrm{~mol} / \mathrm{litter})$ was added slowly until complete saponification, following $10 \%$ hot water $\left(90^{\circ} \mathrm{C}\right)$ was added to homogenous the soap paste. Thereon, $6-8 \%$ hot sodium chloride solution $\left(15 \% \mathrm{Na} \mathrm{Cl}\right.$ at $\left.90{ }^{\circ} \mathrm{C}\right)$ was added gradually 
over the surface of soap during its boiling to reduce the soap viscosity and to separate the glycerol water in the bottom, while saponified mass was floated on the surface. The glycerol water was isolated by siphoning. Therewith, the soap paste was washed again by $(5-10 \%)$ hot water $\left(90^{\circ} \mathrm{C}\right)$ to reduce the amounts excess of sodium hydroxide and sodium chloride with any impurities found in the soap paste. The homogeneity of the soap was tested during and after the saponification process using the finger method, Knife test and the total electrolite (free alkali as $\mathrm{NaOH} \%$ and salt as $\mathrm{NaCl} \%$ ). After that, the soap paste was poured in a wood frame and leted at room temperature for harding, then cutting into small soap bars $(150 \mathrm{~g})$. The quantities of resultant soap samples from eight fatty blends are shown in Table (I). Soap sample $n .{ }^{\circ} 1$ was the standard soap. The obtained soap samples were analyzed for its some chemical and physical properties.

Table I

Composition (\% W/W) and quantities of soap samples made from different ingredients

\begin{tabular}{l|ccccccccc}
\hline \multirow{2}{*}{$\begin{array}{c}\text { Ingredients } \\
\text { and quantities of soap }\end{array}$} & \multicolumn{8}{c}{ Soap blends n. } \\
\cline { 2 - 9 } & 1 & 2 & 3 & 4 & 5 & 6 & 7 & 8 \\
\hline M.P.O. (\%) & 0 & 85 & 10 & 20 & 30 & 40 & 50 & 60 \\
T. (\%) & 85 & 0 & 75 & 65 & 55 & 45 & 35 & 25 \\
P.K.O. (\%) & 15 & 15 & 15 & 15 & 15 & 15 & 15 & 15 \\
\hline Sodium hydroxide (\%) & 17.0 & 16.5 & 17.0 & 17.0 & 17.0 & 17.0 & 17.0 & 17.0 \\
\hline Quantities of the produced soaps (g) & 1275 & 1245 & 1310 & 1315 & 1325 & 1350 & 1355 & 1375 \\
\hline
\end{tabular}

Where: T.: Tallow M.P.O.: Mucilage palm oil P.K.O.: Palm kernel oil.

\section{Chemical properties of soap}

Free alkali content $(\mathrm{NaOH} \%)$, moisture $(\%)$, total fatty matter (T.F.M.\%), free oil (\%), unsaponifiable matter (\%) and unsaponified matter (\%) of the soap samples were determined according to the methods described by The Egyptian Standards (1992) and the A.O.C.S. (1993).

\section{Physical properties of soap}

Color and titer number ${ }^{\circ} \mathrm{C}$ (T.N.) of the obtained soaps were measured according to the methods described in the A.O.C.S. (1993), while foamability of the studied soaps were estimated according to Ainie et al., (1996). Consistency of the derived soaps was evaluated according to Martin (1951). All analysis were done in duplicate and the averages are reported.

\section{RESULTS AND DISCUSSION}

\section{Components of mucilage palm oil}

From results in Table II, it could be observed that the mucilage palm oil contained high free fatty acids content $(82.2 \%)$, while the neutral oil represented a $11.9 \%$. This value for neutral oil is within the range (10-20\% neutral oil) found by Norman (1981). The amount of impurities and unsaponifiable matter were higher $(2.1 \%)$ than that (should not be over than $1.0 \%$ as moisture, impurities and unsaponifiable matter in the fatty materials using in soap) reported by The Egyptian Standards (1992).

Table II

Composition of mucilage palm oil

\begin{tabular}{ccccc}
\hline Contents & $\begin{array}{c}\text { Free fatty acids } \\
(\%)\end{array}$ & $\begin{array}{c}\text { Neutral oil } \\
(\%)\end{array}$ & $\begin{array}{c}\text { Moisture and volatile matter } \\
(\%)\end{array}$ & $\begin{array}{c}\text { Impurities and } \\
\text { unsaponifiable matter } \\
(\%)\end{array}$ \\
\hline Mucilage palm oil & 82.2 & 11.9 & 3.8 & 2.1 \\
\hline
\end{tabular}




\section{Bleaching of the fatty materials}

Considerable differences were noticed between colors of the fatty materials before and after bleaching (Table III). These fatty materials (M.P.O., T. and P.K.O.) were unsuitable for using in the manufacturing of toilet soap. They cause many problems in the color of resulted soap. Wherefore, these fatty materials were bleached until they can be used in the colored toilet soap manufacturing. From results, it can be observed that the color of M.P.O. was improved from deep orange color (13-11 B F.A.C.) before bleaching to yellow color (5-7 near 5 F.A.C.) after bleaching. While in the color of P.K.O. became very light after bleaching, which recorded pale white (less than 1 F.A.C.). On the other hand, color of tallow was slight yellow (3 F.A.C.) after bleaching. These varieties in the colors after bleaching might be attributed to the differences in the colors degree of fatty materials before bleaching. These colors are close to those discussed by Ahmed (1984) and Woollatt (1985) and also they are within the range (should be less than 5 F.A.C.) tabulated by the Ministry of Industry (1992), unless the color of M.P.O., which was higher (5-7 near 5 F.A.C.).

Table III

Changes occured in color (F.A.C.) of the fatty materials before and after bleaching

\begin{tabular}{lccc}
\hline \multirow{2}{*}{ Bleaching time } & \multicolumn{3}{c}{ Color (F.A.C.) of the fatty materials } \\
\cline { 2 - 4 } & M.P.O. & T. & P.K.O. \\
\hline Before bleaching & $13-11 \mathrm{~B}$ & $7-9$ near 7 & $3-5$ near 3 \\
After bleaching & $5-7$ near 5 & 3 & less than 1 \\
\hline
\end{tabular}

All abbreviations as in Table I.

\section{Some characteristics of the fatty materials using in the soap blends}

Data in Table IV clearly shows that moisture and volatile matter of M.P.O. was too much higher (3.8\%) than that (should be less than $0.3 \%$ ) tallied by Ministry of Industry (1992), while in T. and P.K.O., they are in line with that (should be less than 0.3 and $0.5 \%$ for T. and P.K.O., respectively) found by Woollatt (1985). On the other hand, the acidity of M. P.O. was too much higher $(82.2 \%)$ than those determined in T. and P.K.O. (2.8 and $0.5 \%$, respectively). This rise bearable attributed to M.P.O. had high content of free fatty acids than in T. and P.K.O. These values for T. and P.K.O. are in conformance with those (less than $4.0 \%$ ) marked by Woollatt (1985) and the Ministry of Industry (1992). A very slight difference was observed between saponification values of T. and P.K.O. These varieties were almost in as much as the M.P.O. had high contents for each of moisture and unsaponifiable matter ( 3.80 and $0.48 \%$, respectively) than those found in T. (0.28 and $0.32 \%$, respectively), while the saponification value of P.K.O. is within the range (242-250) cited by Ahmed (1981) and Woollatt (1985). Saponification value is used to estimate the sodium hydroxide content requiring for saponified the fatty materials (Woollatt, 1985). As to, iodine value of M.P.O. was higher (44.0) than that (40.1) found in $T$. This increase was nearly due to the difference in unsaturated fatty acids content in M.P.O. than that determined in T. The I.V. of M.P.O. was lower than that (51-55) stated by Ahmed (1981, 1984) for palm oil. This reducement perhaps related to the differences in the fatty acids composition. On the other hand, I.V. of T. is within the range (40-46) found by Bhattacharyya and Chatterjee (1984), while in P.K.O. is in agreement with those (16-20) surveged by Ahmed $(1981,1984)$ and Bhattacharyya and Chatterjee (1984). The obtained results also show that I.N.S. factor of M.P.O. was lower (142.8) than that (153.2) found in T. This diminishment was nearly in view of the increasing in I.V. of M.P.O. (44.0) with decline in the S.V. (186.8). The I.N.S. factors of T. and P.K.O. are close upon with those (152-146 and 224-235 for T. and P.K.O., respectively) estimated by Ahmed (1984) and Bhattacharyya and Chatterjee (1984). I.N.S. factor is used in the soap manufacturing to control the hardness of soap (Ahmed, 1981 and Woollatt, 1985). As seen in Table IV, unsaponifiable matter of M.P.O. was higher $(0.48 \%)$ than that (less than $0.3 \%$ ) remarked by Ministry of Industry (1992), while in T. and P.K.O. are comparable to that (less than $1.0 \%$ ) cleared by Woollatt (1985). On the other hand, they are unlike with that (should not be over than $0.3 \%$ ) assigned by the Ministry of Industry (1992). The unsaponifiable matter is the portion which does not react with alkali during the saponification (Woollatt, 1985 and Gupta, 1991). So much for titer numbers of M.P.O., T. and P.K.O. are in tantamount with those $\left(40-45,38-48\right.$ and $21-27^{\circ} \mathrm{C}$ for P.O., T. and P.K.O., respectively) reported by Ahmed (1981), Bhattacharyya and Chatterjee (1984) and Woollatt (1985). The rises in titer number and I.N.S. factor indicate that the resulted soap is hard consistency, and vice versa (Ginn et al., (1968), Ahmed (1984) and Kifli and Krishnan (1988).

\section{Fatty acids content in M.P.O., T. and P.K.O.}

Data represented in Table $V$ shows the fatty acids composition of the fatty materials using in this work. The main saturated fatty acid in M.P.O. was palmitic acid $(44.3 \%)$, while oleic acid was the major unsaturated fatty acid $(38.9 \%)$ of the total fatty acid. This result is to conform with many investigator 
[Ahmed (1981, 1984), Bhattacharyya and Chatterjee (1984) and Woollatt (1985)]. Oleic acid was found in higher quantities in tallow (42.5\%). On the other hand, P.K.O. had a high content of lauric acid $(50.8 \%)$. These values for tallow and P.K.O. are symmetrized with those estimated by Young (1983), Bhattacharyya and Chatterjee (1984) and Woollatt (1985). Lauric, palmitic, stearic and oleic acids are responsible for the lathering and washing properties of soap (Ainie et al., 1996).

Table IV

Some physical and chemical characteristics of the fatty materials

\begin{tabular}{|c|c|c|c|c|c|c|c|c|c|}
\hline $\begin{array}{l}\text { Fatty } \\
\text { materials }\end{array}$ & Character & $\begin{array}{l}\text { Moisture and } \\
\text { volatile matter (\%) }\end{array}$ & Acidity (\%) & $\begin{array}{l}\text { Saponification } \\
\text { value (S.V.) }\end{array}$ & $\begin{array}{l}\text { lodine value } \\
\text { (I.V.) }\end{array}$ & I.N.S. Factor & $\begin{array}{l}\text { Unsaponifiable } \\
\text { matter (\%) }\end{array}$ & $\begin{array}{c}\text { Titer number }{ }^{\circ} \mathrm{C} \\
\text { (T.N.) }\end{array}$ & $\begin{array}{l}\text { Color } \\
\text { (F.A.C.) }\end{array}$ \\
\hline & M.P.O. & 3.80 & 82.2 (palmitic) & 186.8 & 44.0 & 142.8 & 0.48 & 42.5 & $13-11 \mathrm{~B}$ \\
\hline & T. & 0.28 & 2.8 (oleic) & 193.3 & 40.1 & 153.2 & 0.32 & 41.5 & $7-9$ near 7 \\
\hline & P.K.O. & 0.11 & 0.5 (lauric) & 245.0 & 17.2 & 227.8 & 0.10 & 26.0 & $3-5$ near 3 \\
\hline
\end{tabular}

All abbreviations as in Table I.

Table V

Distribution of the fatty acids in mucilage palm oil, tallow and palm kernel oil

\begin{tabular}{cccccccccccc}
\hline Fatty materials & $C_{8: 0}$ & $c_{10: 0}$ & $c_{12: 0}$ & $c_{14: 0}$ & $c_{16: 0}$ & $c_{16: 1}$ & $c_{18: 0}$ & $c_{18: 1}$ & $c_{18: 2}$ & $c_{18: 3}$ & Others \\
\hline M.P.O. & 0 & 0 & 0.8 & 2.6 & 44.3 & 0.1 & 5.3 & 38.9 & 7.4 & 0.4 & 0.2 \\
T. & 0 & 0 & 0.3 & 3.4 & 28.9 & 0.5 & 18.6 & 42.5 & 5.2 & 0.3 & 0.3 \\
P.K.O. & 4.0 & 5.1 & 50.8 & 15.6 & 7.2 & 0 & 1.9 & 13.0 & 2.2 & 0 & 0.2 \\
\hline
\end{tabular}

All abbreviations are shown in Table I.

\section{Some chemical properties of the derived soaps}

Moisture contents of eight soap samples $\left(n .{ }^{0 s} 1-8\right)$ are tabulated in Table VI. Wide differences were observed between moisture contents of seven soap samples $\left(n{ }^{.5} 2-8\right)$ compared with the control sample (soap n. ${ }^{\circ}$ 1). These variations might be ascribed to the used content of mucilage palm oil (M.P.O.) in these blends, which were higher $(85,10,20,30,40$, 50 and $60 \%$ for soap blends n. ${ }^{\circ} 2,3,4,5,6,7$ and 8 , respectively) than that used in the standard soap (zero M.P.O.). All moisture amounts of eight soap samples are higher than that $(6-8 \%)$ reported by Anine et al., (1996). These changes were nearly owing to the difference in the soap preparing methods. On the other hand, the total fatty matter (T.F.M.) of the same soaps $\left(n .^{\circ s} 2-8\right)$ decreased. These changes in T.F.M. were actually fairly low than that obtained in the control soap $(71.8 \%)$, except in soap n. ${ }^{\circ} 2$, where was very low $(68.0 \%)$. These differences in the T.F.M. of all soaps contingent led to the changes in their moisture contents. Ogoshi and Migawaki (1985) and Hui (1996) stated that the total fatty matters in the neat toilet soap were between the range $65-70 \%$. Therefore, these results are coincide with those declared by these investigators, except soap samples $n^{.0} 1,3$ and 4 , which were higher $(71.8,71.5$ and $71.1 \%$, respectively). These varieties probably assigned to the various in kinds and quantities of the used fatty materials and also perhaps due to the difference in the saponification method. The obtained results in Table VI also show the free alkali content of all soap samples (n. $\left.{ }^{\text {s }} 1-8\right)$, which were slight higher in seven samples $n .^{\text {os }} 2-8$ than that $(0.06 \%)$ estimated in the control soap $\left(n .^{\circ} 1\right)$. These increases almost ascribed to the soap samples $n .{ }^{\text {s }} 2-8$ had high moisture contents at different ratios compared with the control soap. These data are in harmony with those (should be less than $0.1 \%$ as $\mathrm{NaOH}$ ) tallied by The Egyptian Standards (1992) and Ainie et al., (1996) for Malaysian soap. Respect, the free oil of 7 soap samples $\left(n .{ }^{\circ} 2-8\right)$ were greater than that $(0.32 \%)$ surveged in the control soap $\left(n .^{\circ} 1\right)$. These rises possibly attributed to the content of unsaponifiable matter in M.P.O. was high $(0.48 \%)$. The abovementioned results are equal with those (should be less than $0.5 \%$ ) listed by Martin (1951) and The Egyptian Standards (1992). The unsaponifiable matters of soap samples $n .{ }^{\text {os }} 2-8$ were slightly higher 
than that determined in the control sample $\left(n .^{\circ} 1\right)$, except in samples $n .^{\circ s} 2,7$ and 8 , which were very high $(0.41,0.37$ and $0.39 \%$, respectively). These increases were nearly owing to the percentage of unsaponifiable matter in M.P.O. was very high $(0.48 \%)$. On the other hand, the Egyptian specification for unsaponified matter in toilet soap is limited, which should be less than $0.1 \%$ (The Egyptian Standards,
1992). Hence, the unsaponified matters of all soap samples (n. $\left.{ }^{\text {os }} 1-8\right)$ are within the range $(<0.1 \%)$ indicated by Woollatt (1985) and The Egyptian Standards (1992), except two soap samples n. ${ }^{\text {s }} 6$ and 8 , which were slightly higher $(0.11$ and $0.12 \%$, respectively). Low unsaponified matter content indicates that the saponification is full dark, and vice versa (Gupta, 1991).

Table VI

Some chemical properties of the fresh soap samples

\begin{tabular}{|c|c|c|c|c|c|c|}
\hline Soap blend $\mathrm{n}^{\circ}$ Character & $\begin{array}{c}\text { Moisture } \\
(\%)\end{array}$ & $\begin{array}{c}\text { T.F.M. } \\
(\%)\end{array}$ & $\begin{array}{l}\text { Free alkali } \\
\text { ( } \mathrm{Na} \mathrm{OH} \mathrm{\% )}\end{array}$ & $\begin{array}{c}\text { Free oil } \\
(\%)\end{array}$ & $\begin{array}{c}\text { Unsaponifiable } \\
\text { matter (\%) }\end{array}$ & $\begin{array}{c}\text { Unsaponified } \\
\text { matter (\%) }\end{array}$ \\
\hline 1 & 18.3 & 71.8 & 0.06 & 0.32 & 0.27 & 0.05 \\
\hline 2 & 22.5 & 68.0 & 0.09 & 0.48 & 0.41 & 0.07 \\
\hline 3 & 18.8 & 71.5 & 0.06 & 0.38 & 0.30 & 0.08 \\
\hline 4 & 19.5 & 71.1 & 0.07 & 0.39 & 0.31 & 0.08 \\
\hline 5 & 20.4 & 70.0 & 0.07 & 0.43 & 0.33 & 0.10 \\
\hline 6 & 21.0 & 69.3 & 0.08 & 0.45 & 0.34 & 0.11 \\
\hline 7 & 21.9 & 68.3 & 0.08 & 0.47 & 0.37 & 0.10 \\
\hline 8 & 22.5 & 67.8 & 0.09 & 0.51 & 0.39 & 0.12 \\
\hline
\end{tabular}

Where: T.F.M.: Total fatty matter.

\section{Some physical characteristics of the resultant soap}

From Table VII, it is seen that the color of soap samples $n .^{\text {os }} 2-8$ were within the range from 3 to 5-7 near 7 F.A.C. These colors of the same soaps $\left(n{ }^{0 s} 2-8\right)$ were higher than that (less than 3 F.A.C.) measured in the control soap $\left(n .^{\circ} 1\right)$. These variations were suspected due to the color of M.P.O. using in the soap blends, which was yellow (5-7 near 5 F.A.C.). While the colored Egyptian toilet soap base should not be over than 5 F.A.C. (Ministry of Industry, 1992). Hence, the color of soaps $n .{ }^{\text {os }} 2,7$ and 8 were deeper (5-7 near 7, 5-7near 5 and 5-7 F.A.C., respectively) and from that, it can be resulted that the fatty acids color of samples n. ${ }^{\circ s} 2,7$ and 8 are out of character for using in the manufacturing of toilet soap, while the other soap samples $\left(n .^{\circ s} 3,4,5\right.$ and 6$)$ are fit for using as a toilet soap. Also Table VII shows the

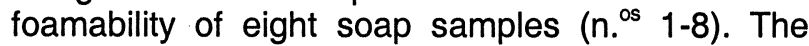
lather volumes of soap samples $n .^{\text {os }} 2-8$ were lower than that $(450 \mathrm{ml})$ surveged in the control soap $\left(\mathrm{n}^{\circ}{ }^{\circ}\right)$. These reducements bearable related to the fatty acids composition of fatty materials using in these soap blends were differents. On the other hand, the foam volumes of soaps were in the following increasing order: $n .^{\text {os }} 1>n .^{\circ} 3>n .^{\circ} 4 n .^{\circ} 5>n .{ }^{\circ} 6>$ n. ${ }^{\circ} 7>$ n. $^{\circ} 8>$ n. $^{\circ} 2(450,440,435,430,420,410$,
395 and $380 \mathrm{ml}$., respectively). These changes were nearly in view of the used content of M.P.O. in those blends, which were varieties. These findings are simillar with those reported by Kifli and Krishnan (1988), Ainie and Hamirin (1994) and Ainie et al., (1996), who showed that the soap made from a blend of $85 \%$ palm oil with $15 \%$ P.K.O. gave moderate lathering properties with hard body. From data in Table VII, it can be observed that lathering properties of the derived soaps were decreasement with increasing M.P.O. content used, because it had a high palmitic acid (44.3\%). Lauric and myristic acids are responsible for the lathering properties of toilet soap, while palmitic and oleic acids are contribute to the washing properties of soap (Ainie et al., 1996). The lather volume of all soaps were higher than that $(345 \mathrm{ml})$ found in Japaness toilet soap, which discussed by Ainie et al., (1996). These increases were presumably due to the difference of fatty materials using in these soaps. The foamability of soap samples $n .^{\text {os }} 3,4,5,6,7$ and 8 were higher than that $(380 \mathrm{ml})$ found in soap $n .^{\circ} 2$, but these values were lower than that $(450 \mathrm{ml})$ determined in the control soap $\left(n .^{\circ} 1\right)$. These differences might be attributed to the content used of M.P.O. in soap blend $\mathrm{n} .^{\circ} 2$, which was too much high (85\%). Hence, it can be noticed that, the soap samples $n .^{\text {os }} 3,4,5$ and 6 are the best in the foamability properties and color 
quality. Titer number of seven soaps (n. $\left.{ }^{\text {os }} 2-8\right)$ were close neighbor with that $\left(39.1^{\circ} \mathrm{C}\right)$ estimated in the standard soap $\left(n .^{\circ} 1\right)$. These values are within the range $\left(39-43^{\circ} \mathrm{C}\right)$ studied by Ainie et al., (1996) for Malaysian toilet soap. On contrasting, these results are lower than that $\left(40-42{ }^{\circ} \mathrm{C}\right)$ recorded by Bhattacharyya and Chatterjee (1984), except soap $\mathrm{n} .{ }^{\circ} 2$, which is within the range $\left(40.2^{\circ} \mathrm{C}\right)$. On the other hand, these findings (T.N. of seven soaps $n .^{.5} 2-8$ ) are higher than that $\left(30-38{ }^{\circ} \mathrm{C}\right)$ determined in European toilet soap, which marked by Ainie et al., (1996). The consistencies of all soap samples $\left(n .{ }^{\circ s} 2-8\right)$ were equal to that obtained in the standard soap $\left(n .{ }^{\circ} 1\right)$, which was hard.These findings are in harmony with that described by Ahmed (1984), who cited that the soaps made from a blend of $80 \%$ palm oil with $20 \%$ palm kernel oil was firm structure. Subsequently, it can be noticed that the consequent soap from blends n. $^{\circ 5} 3,4,5$ and 6 were near close to the standard soap (sample n. ${ }^{\circ} 1$ ) in physical characteristics, such as hard body with rich lather and good color. Therefore, four soap samples $\left(n .^{\text {os }} 3-6\right)$ are suitable for using. At the same time, from above results, it can be noticed that the better soap samples for physical properties were in the following increasing order: $n .^{\circ} 3>n .^{\circ} 4>n .{ }^{\circ} 5>n .{ }^{\circ} 6$, which had firm structure with creamy foam. On the other hand, the resultant soaps from blends $n^{\text {os }} 2,7$ and 8 gave low foamability with deep color. Thereon, they may not be handsome for using. These perhaps related to the high content of M.P.O., which used at ratio of 85,50 and $60 \%$ in blends $n .{ }^{\circ s} 2,7$ and 8 , respectively.

Table VII

Some physical properties of the resultant soap samples

\begin{tabular}{|c|c|c|c|c|c|c|c|c|}
\hline Soarameter & 1 & 2 & 3 & 4 & 5 & 6 & 7 & 8 \\
\hline $\begin{array}{l}\text { Color of the fatty acids } \\
\text { (F.A.C.) }\end{array}$ & $\begin{array}{c}\text { less than } \\
3\end{array}$ & $\begin{array}{c}5-7 \\
\text { near } 7\end{array}$ & 3 & $\begin{array}{c}3-5 \\
\text { near } 3\end{array}$ & $\begin{array}{c}3-5 \\
\text { near } 5\end{array}$ & 5 & $\begin{array}{l}5-7 \\
\text { near } 5\end{array}$ & $5-7$ \\
\hline Foamability (ml) & $450 / 285^{b}$ & $380 / 220^{b}$ & $440 / 275^{b}$ & $435 / 270^{b}$ & $430 / 265^{b}$ & $420 / 250^{b}$ & $410 / 245^{b}$ & $395 / 235^{b}$ \\
\hline Titer number $\left({ }^{\circ} \mathrm{C}\right)$ & 39.1 & 40.2 & 39.2 & 39.5 & 39.4 & 39.6 & 39.8 & 39.9 \\
\hline Structure & hard & hard & hard & hard & hard & hard & hard & hard \\
\hline
\end{tabular}

Where: $b$ : is volume of foam after $5 \mathrm{~min}$.

Therefore, from these results, it could be recommended that mucilage palm oil can be used in the fatty blend of toilet soap at ratio of $40 \%$, which gives fine quality characteristics in the consequent soaps, such as good lathering properties and hard consistency with good color.

\section{ACKNOWLEDGMENT}

The author wish to staff of Central Laboratory, Cairo Oils and Soap Company, Cairo, Egypt, for their help in preparing this work.

\section{REFERENCES}

Ahmed, I. (1981).- -Use of palm stearin in soap, occasional paper $n .^{\circ} 2 »$.-Palm Oil Research Institute of Malaysia (PORIM), Selangor, Malaysia, 1-9.

Ahmed, I. (1984).- «Significance of palm oil and palm stearin as fatty raw materials for soap, occasional paper n. 19".-Palm Oil Research Institute of Malaysia (PORIM), Selangor, Malaysia, 1-17.

Ainie, K. and Hamirin, K. (1994).— «Palm-based soap in selected readings on palm oil and its uses".-Palm Oil
Research Institute of Malaysia (PORIM), Selangor, Malaysia, 183-196.

Ainie, K., Hamirin, K. and Peang-Kean, L. (1996)."Chemical and physical characteristics of soap made from distilled fatty acids of palm oil and palm kernel oil».-J. Am. Oil Chem. Soc. 73, 105-108.

A.O.C.S. (1993).— - Official and Tentative Methods for the American Oil Chemists'Society" $-6^{\text {th }}$ ed. Published by the American Oil Chemists'Society, Champaign, U.S.A.

Bhattacharyya, D.K. and Chatterjee, B. (1984).- «Palm oil fatty acids in soap and detergent formulations".-J. Am. Oil Chem. Soc. 61, 417-419.

Chamkasem, N. and Johnson, L.A. (1988).- «Colour stability of glandless cottonseed oil».-J. Am. Oil Chem. Soc. 65, 1778-1780.

Edmund, D.G. (1994).— «Fatty acid distribution of fats, oils and soaps by high-performance liquid chromatography without derivatization».-J. Am. Oil Chem. Soc. 71, 789-791.

Hamilton, R.J. (1995).- «Developments in oils and fats".Blackie Academic and Professional, London, 156.

Hui, Y.H. (1996)._ «Soap. In: Bailey's industrial oil and fat products".-A Wiley Interscience Publication, John Wiley and Sons Inc., New York, Vol. 5, 93.

Ginn, M.E., Steinhauer, R.C., Liebman, D. and Eungermann, E. (1968). - «Effect of tallow-coconut fatty acid ratios on properties of bar soaps".-J. Am. Oil Chem. Soc. 45, 666-669. 
Gupta, S. (1991).- «Soap technology for the 1990's».American Oil Chemists'Society, Champaign, 48-63. Jan, C. (1995).—- «Physical refining of edible oils».-J. Am. Oil Chem. Soc. 72, 1193-1196.

Joseph, C.D. and Desal, D.D. (1991)._ «Liquid laundry detergents based on soap and $\alpha$-sulfo methyl esters".-J. Am. Oil Chem. Soc. 68, 59-62.

Karl, I.Z. (1991).— «By-product utilization. In: Introduction to fats and oils technology".-Published by the American Oil Chemists'Society, Illinois, U.S.A., Vol. 1, 263.

Kifli, H. and Krishnan, S. (1988)._-Palm oil products in soap making including measurement of properties of the soap developed, in proceedings of the 1987 international oil $\mathrm{palm} / \mathrm{palm}$ oil conference-progress and prospects".-Conference II: Technology, Palm Oil Research Institute of Malaysia (PORIM), Selangor, Malaysia, 304-315.

Martin, G. (1951).- «The modern soap and detergent industry".-The Tech. Press Ltd.. London, Vol. 2, p. 5, 11.

Ministry of Industry (1992).— «The annual report of the Egyptian Industrials Food Organization», Cairo, Egypt.

Ministry of Industry (1997).- «The annual report of the Egyptian Industrials Food Organization», Cairo, Egypt

Ministry of Trade and Supply (1997).- «The annual report of General Organization for Control on Exports and Imports", Cairo, Egypt.

Norman, O.V.S. (1981).- «Current future fat-based raw materials for soap manufacture".-J. Am. Oil Chem. Soc. 58,155A-161A.

Ogoshi, T. and Migawaki, Y. (1985).-«Soap and related products: palm and lauric oil».-J. Am. Oil Chem. Soc. 62, 331-335.
Small Business Publications (S.B.P.). (1987).—«Technology of laundry and toilet soaps".-Chemical Engineering Series n. 44, Delhi, 32.

Stahl, E. (1967).- «Thin layer chromatography. A Laboratory Handbook».-Springer Verlag, Berlin, 359.

Tan, Y.A., Ong, S.H., Berger, K.G., Oon, H.H. and Poh, B.L. (1985). - "A study of the cause of rapid colour development of heated refined palm oil».-J. Am. Oil Chem. Soc. 62, 999-1006.

Tandy, D.C. and McPherson, W.J. (1984)._«Physical refining of edible oil».-J. Am. Oil Chem. Soc. 61,1253-1258.

The Egyptian Standards (1992)._- Egyptian Standard (1044/1992) for soap, Egyptian Organization for Standardization and Quality Control».-Ministry of Industry, Cairo, Egypt.

Woollatt, E. (1985). - "The manufacture of soaps, other detergents and glycerine".-1. ${ }^{\text {st }}$ ed. Ellis Howood Ltd., Chester, England, p. 46, 126, 135, 139.

Young, F.V.K. (1983)._- «alm kernel and coconut oils: analytical characteristics, process technology and uses".-J. Am. Oil Chem. Soc. 60, 326A-331A.

Zygadlo, J.A., Morero, R.E., Abburra, R.E. and Guzman, C.A. (1994).— «Fatty acid composition in seed oils of some onagraceae».-J. Am. Oil Chem. Soc. 71, 915-916.
Recibido: Abril 1998 Aceptado: Octubre 1998 